\title{
FRAMING THE GENDER EQUALITY IN IAIN PONOROGO INDONESIA
}

\author{
Anis Hidayatul Imtihanah \& Asep Syahrul Mubarok \\ IAIN Ponorogo \\ anis.hidayatulhanah@gmail.com, ustadzsh@gmail.com
}

\begin{abstract}
Women play many roles in today's world in their societies' economic development. Women have many contributions to a country's welfare in various sectors, such as politic, health, agriculture, and public education. This research used a mixed-method design to analyze Islamic higher education, focusing on implementing gender policy and gender values-moreover, the activities of female lecturers in their daily work. The research also combines qualitative and quantitative data-gathering methods, particularly participant observation, in-depth interviews, numbers data, and figures to analyze how gender equality values for women should be implemented. This research reveals that IAIN Ponorogo is responsive gender. It can be seen from women's involvement in multiple fields like the academic senate member and the journal manager. The research also argues that women should be given equal opportunities as men, including paid work and the decisionmaking position sectors, to contribute to the institution.
\end{abstract}

Keywords: Women Participation, Gender Equality, Islamic Higher Education.

\section{Abstrak}

Perempuan memiliki banyak peranan dalam kehidupan sosial. Perempuan juga berkontribusi terhadap kesejahteraan negara melalui berbagai sektor seperti politik, kesehatan, pertanian dan pendidikan. Penelitian ini menggabungkan metode qualitatif dan kuantitaf (mixed-method) dalam 
memotret PTKI terutama dalam penerapan nilai-nilai dan kebijakan gender yang berpihak terhadap dosen perempuan. Pengumpulan data melalui observasi, wawancara, serta data yang berupa angka dan gambar untuk menganalisis bagaimana nilai-nilai kesetaraan gender tersebut diterapkan. Hasil penelitian ini menunjukkan bahwa IAIN Ponorogo termasuk dalam kategori perguruan tinggi yang responsif gender. Hal tersebut tampak dalam keterlibatan dosen perempuan di berbagai bidang seperti keanggotaan senat akademik dan sebagai pengelola jurnal. Dengan demikian perempuan harus diberikan akses yang sama seperti halnya lakilaki untuk berkontribusi kepada lembaga perguruan tinggi.

Kata kunci: Partisipasi Perempuan, Kesetaraan Gender, Perguruan Tinggi Islam.

\section{INTRODUCTION}

Higher education is an ivory tower and a lighthouse expected to provide advancement through all its thoughts, breakthroughs, and innovations. Higher education is a role model that all levels of society can follow to lead to a better life order in terms of education, social, economic and political. Likewise, gender relations in higher education are also in the spotlight. The issue of gender relations in higher education is an exciting topic to study because this aims to reveal the veil of equality between men and women in higher education.

This article presents a gender profile at IAIN Ponorogo. It gives related data to analyze and describe relations between all academics, whether they have shown and represented equality between men and women. The equality covers equality in gaining access to structural positions, making and determining campus policies, and managing scientific journals.

Higher education also plays a role as one of the government's partners in realizing a civil society structure. Civil society means an open mind in all aspects in general and gender equality in particular. Universities can do this by implementing autonomy policies that exist within the university environment. Several scopes of higher education autonomy are as follows:

1. Students have the rights to learn, and lecturers have the rights to teach according to their respective interests.

2. Higher education has the right to set its priorities and carry out scientific research in any direction by considering society's interests. 
3. Higher education is tolerant of differences of opinion and free from political interference.

4. Higher education as a public institution through education and research must develop fundamental freedom and justice, humanity and solidarity. It is obliged to help one another, both materially and morally, in a national and international context.

5. Higher education is obliged to disseminate and develop science, technology and art.

6. Higher education avoids intellectual hegemony.

7. Higher education has the right and responsibility to use their resources independently to support their activities. ${ }^{1}$

Meanwhile, the discourse on gender seems to be never-ending and timeless. Gender issues are always interesting to be raised and voiced with all the pros and cons. It all boils down to equal access between men and women in the public sphere. So far, gender studies are still about the division of the roles of husband and wife. Traditionally, the husband is the provider, while the wife is the housekeeper. ${ }^{2}$ However, currently, gender studies also include agency, namely the capacity and ability of women to make decisions, make choices, and be free from all forms of violence and fear. ${ }^{3}$ Likewise, regarding gender issues in higher education to measure how far awareness of the application of gender values. So, it is deemed appropriate to hold the title of a gender-friendly campus.

Gender mainstreaming is also one of the UN Women's agendas so that women have equal access in the fields of education, health, politics, and economics. Gender mainstreaming is applied in various fields, one of which is in the education sector. Various forms and efforts have been made, including improving human resources for both men and women. The Center for Gender and Child Studies at Islamic Higher Education indicates that gender awareness in higher education is relatively high. There are many activities held by the Center for Gender and Child Studies, ranging from workshops,

1 Richardus Eko Indrajit \& Richardus Djokopranoto, Manajemen Perguruan Tinggi Modern (Jakarta: Atma Jaya\&Perbanas, 2006), p. 18.

2 F. Ivan Nye, Role Structure and Analysis of the Family (USA: Sage Publication, 1976), p. 98.

3 Amina Jamal, 'Gendered Islam and Modernity in the Nation-Space: Women's Modernism in the Jamaat-e-Islami of Pakistan', Feminist Review, vol. 91, no. 1 (2009), p. 13 . 
publications to pro-gender policy reviews. Everything comes down to minimize and even eliminate the gender gap to achieve equality and justice for all. ${ }^{4}$

This article is not the first article to discuss gender relations in higher education. Inayatillah ${ }^{5}$, wrote an article discussing a similar topic entitled Portraits of Gender Relations at UIN Ar-Raniry. The gender relation of the academic community and students to identify gaps in gender relations at UIN Ar-Raniry was exposed. Furthermore, Dingse Pandiangan et al. ${ }^{6}$, wrote an article focusing on the proportion of leadership representing gender values at Sam Ratulangi University. It affirmed the balance of students' number based on gender equality and the need to accommodate activities aimed at increasing gender awareness in universities.

Furthermore, research on the performance of female lecturers at UNIKOM is based on gender relations. Because the gender-based relationship pattern will make female lecturers produce optimal performance, this study's results indicate that gender relations among UNIKOM lecturers are not yet thoroughly gendered, because there are still many activities that are not gender-based, especially in research and community service. This has a negative impact because it hinders these activities' success. ${ }^{7}$

Based on the previous research studies' search results, this article shows its position and an exciting side. In this article, the data on female lecturers' involvement as managers of scientific journals and female lecturers' participation in research grants held internally by higher education are presented. This article also displays women's progress in higher education from various sides, such as female lecturers' position in the academic senate membership and the involvement of female lecturers as managers of scientific journals.

The data in this study were identified using mixed methods, combining

${ }^{4}$ Michael Pye et. al., Religious Harmony; Problem, Practice, and Education (Jerman: 2006), p. 164.

5 Inayatillah, 'Potret Relasi Gender di UIN Ar-Raniry', Gender Equality: International Journal of Child and Gender Studies, vol. 3, no. 2, September 2017, pp. $49-66$ [https:// jurnal.ar-raniry.ac.id/index.php/equality/article/view/3442].

6 Dingse Pandiangan et al., 'Profil Gender Sumber Daya Manusia Universitas Sam Ratulangi Tahun 2019 Berbasis Penilaian Gender (Gender Assessment)', JPAI: Jurnal Perempuan dan Anak Indonesia, vol. 2, no. 1, 2020, pp. 31-42. [https://ejournal. unsrat.ac.id/index.php/jpai/article/view/28277].

7 Nia Karniawati, Kinerja Dosen Perempuan: Studi Relasi Gender di Unikom, Unikom Repository 2013. [https://repository.unikom.ac.id/30655/]. 
and integrating qualitative and quantitative research models. ${ }^{8}$ Displaying data in the form of descriptions of interview results and numerical data in tables was done. Meanwhile, the analysis model was combining statistical and text analysis. The narrative style of analysis displaying the results of research on the gender equality profile at IAIN Ponorogo in the form of descriptions that explain the flow of the research process to the results was also used. ${ }^{9}$

\section{DISCUSSION}

\section{Overview of IAIN Ponorogo}

The Ponorogo State Islamic Institute (IAIN) existence cannot be separated from its root, namely the Abdul Wahhab Sharia Academy as its embryo, founded in 1968. This academy then changed its status to a state institute called the Ponorogo Sharia Faculty of IAIN Sunan Ampel in 1970 by organizing a baccalaureate program. Furthermore, it grew and developed starting in 1985/1986 by organizing an undergraduate program.

In addition to changes in name and status, this campus has also experienced several location changes. Until finally, in 1981, the campus location was settled on 156 Pramuka street Ponorogo. While on Pramuka street, the Ponorogo Sharia Faculty of IAIN Sunan Ampel experienced very significant development. In 1997 it officially changed its status to become an autonomous state university with the name State Islamic College (STAIN) Ponorogo. The last one was in 2016, which increased its status to the State Islamic Institute of Ponorogo (IAIN). ${ }^{10}$ In the future, it is hoped that with the spirit of hard work, cooperation, and synergy with the entire academic community, IAIN Ponorogo will continue developing with enthusiasm in its vision, namely as a center for the study and development of Islamic science that excels to realize civil society.

\section{Students of IAIN Ponorogo}

In this context, the total number of IAIN Ponorogo students in 2020

\footnotetext{
${ }^{8}$ John W. Creswell, Research Design; Qualitative, Quantitative, and Mixed Methods Approaches (USA: Sage Publication, 2014)

9 Howard S. Becker, Tricks of the Trade; How to Think about Your Research While You're Doing It (USA: The University of Chicago Press, 1998), p. 75.

${ }^{10}$ IAIN Ponorogo, Buku Wisuda 2019 Semester Gasal Tahun Akademik 2019/2020 (IAIN Ponorogo, 2019)
} 
was 12,472 , with a total of 8,460 women and 4,012 men. This data shows that the overall IAIN Ponorogo students are dominated by women, with a percentage of $68 \%$ versus $32 \%$.

\section{Number of IAIN Ponorogo Students in 2020}

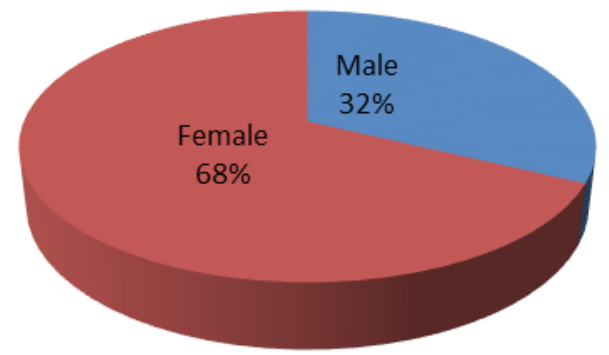

Source: Academic and Student Affairs sub-division, Bureau of General Administration, Academic and Student Affairs, IAIN Ponorogo

From the diagram above, it can be seen that the number of female students is twice as large as male students. This could imply that the study enthusiasts at IAIN Ponorogo were more from women. From the data on the development of students of IAIN Ponorogo from year to year, including since IAIN Ponorogo still has STAIN status, it is even more evident. The following is a table of the number of students entering IAIN Ponorogo:

Table 1. Students of IAIN Ponorogo

\begin{tabular}{|c|c|c|c|c|c|}
\hline \multirow{2}{*}{ Year } & \multicolumn{2}{|c|}{$\begin{array}{c}\text { Number of Undergraduate } \\
\text { Students }\end{array}$} & \multicolumn{2}{|c|}{$\begin{array}{c}\text { Number of Graduate } \\
\text { Students }\end{array}$} & \multirow{2}{*}{ Total Number } \\
\cline { 2 - 5 } & Male & Female & Male & Female & \\
\hline 2013 & 433 & 753 & 0 & 0 & 1186 \\
\hline 2014 & 399 & 891 & 0 & 0 & 1290 \\
\hline 2015 & 518 & 1000 & 68 & 46 & 1632 \\
\hline 2016 & 561 & 1340 & 89 & 49 & 2039 \\
\hline 2017 & 670 & 1570 & 60 & 69 & 2369 \\
\hline 2018 & 793 & 1859 & 60 & 62 & 2774 \\
\hline 2019 & 835 & 2059 & 67 & 60 & 3021 \\
\hline
\end{tabular}




\begin{tabular}{|c|c|c|c|c|c|}
\hline 2020 & 847 & 1867 & 39 & 50 & 2803 \\
\hline Total Number & $\mathbf{5 0 5 6}$ & $\mathbf{1 1 3 3 9}$ & $\mathbf{3 8 3}$ & $\mathbf{3 3 6}$ & $\mathbf{1 7 1 1 4}$ \\
\hline
\end{tabular}

Source: Academic and Student Affairs sub-division, Bureau of General Administration, Academic and Student Affairs, IAIN Ponorogo

On the whole, the study enthusiasts at IAIN Ponorogo seem to be more dominated by women. However, by looking at the development data in the table above, it can be seen that domination occurs at the bachelor's degree. In comparison, at the master's degree, male and female enthusiasts are relatively balanced. This condition can be understood that Ponorogo and surrounding women have an excellent opportunity to access higher education institutions.

Although access to higher education has equal opportunities, there is something that still needs to be paid attention to, namely student access to institute organizations. The following is a table of Student Senate and Student Executive Council data from IAIN Ponorogo:

Table 2. The Membership of Student Senate and Student Executive Council

\begin{tabular}{|c|c|c|c|c|c|}
\hline \multirow{2}{*}{ No } & \multirow{2}{*}{ Year } & \multicolumn{2}{|c|}{ Student Senate } & \multicolumn{2}{c|}{ Student Executive Council } \\
\cline { 3 - 6 } & & Male & Female & Male & Female \\
\hline 1 & 2017 & 12 & 2 & 8 & 7 \\
\hline 2 & 2018 & 11 & 7 & 11 & 11 \\
\hline 3 & 2019 & 8 & 4 & 15 & 7 \\
\hline 4 & 2020 & 4 & 2 & 8 & 2 \\
\hline
\end{tabular}

Source: Management Decree of IAIN Ponorogo Student Senate and Student Executive Council

From these data, it can be seen that it is still dominated by men in student organizations, except in 2018 for the Student Executive Council organization. This contrasts with the number of IAIN students which are more dominated by women. Of course, this is a particular concern which needed to improve gender equality in the Institute's organization.

\section{Civil Servants of IAIN Ponorogo}

The next presentation is data of IAIN Ponorogo civil servants' total number based on work units, as illustrated in the table below. The identification results show that the total number of civil servants at IAIN Ponorogo in 2020 was 209 people, of which 127 male civil servants outperformed 
female civil servants, who were only 82 . The most extensive distribution was in the Faculty of Tarbiyah and Teacher Training with 72 people, followed by the Faculty of Sharia with 34 people and the Faculty of Islamic Economics and Business with 22 people. The three faculties have an almost equal ratio between the number of male and female lecturers. The least was the number of lecturers at the Faculty of Ushuluddin, Adab and Da'wa, which only had 18 people, and most of them were male lecturers. The rest occupied positions were in non-structural institutions, including the Bureau of General Administration, Academic and Student Affairs, Institute for Research and Community Service, Quality Assurance Agency, Internal Control Unit, Information Technology and Data Center, and Library.

Table 3. Civil Servants of IAIN Ponorogo

\begin{tabular}{|c|l|c|c|c|}
\hline \multirow{2}{*}{ No. Work Unit } & \multicolumn{2}{c|}{ Gender } & \multirow{2}{*}{ Total } \\
\cline { 3 - 4 } & & Male & Female & \\
\hline 1 & Rector & 0 & 1 & 1 \\
\hline 2 & Vice Rector & 3 & 0 & 3 \\
\hline 3 & Faculty of Tarbiyah and Teacher Training & 39 & 33 & 72 \\
\hline 4 & Faculty of Ushuluddin, Adab and Da'wa & 13 & 5 & 18 \\
\hline 5 & Faculty of Islamic Economics and Business & 12 & 10 & 22 \\
\hline 6 & Faculty of Sharia & 17 & 17 & 34 \\
\hline 7 & Postgraduate & 11 & 2 & 13 \\
\hline 8 & $\begin{array}{l}\text { Bureau of General Administration, Academic } \\
\text { and Student Affairs }\end{array}$ & 18 & 8 & 26 \\
\hline 9 & Institute for Research and Community Service & 2 & 2 & 4 \\
\hline 10 & Quality Assurance Agency & 3 & 0 & 3 \\
\hline 11 & Internal Control Unit & 1 & 0 & 1 \\
\hline 12 & Information Technology and Data Center & 3 & 0 & 3 \\
\hline 13 & Library & 5 & 4 & 9 \\
\hline & & 127 & 82 & 209 \\
\hline
\end{tabular}

Source: Ministry of Religion Personnel Management Information System / 28/09/2020 08:18

The rise of education, especially for women, has opened up possibilities for new ways of seeing and even new awareness of women's social roles in society. In the pre-modern era, public life seemed to belong only to men. Nevertheless, now, discussions on public issues also need to involve women. 
Women no longer only play a role in the domestic sphere. Women also have a concept of how to manage public space and life together with men. ${ }^{11}$

\section{Membership of IAIN Ponorogo Academic Senate}

The next one is the membership of IAIN Ponorogo Academic Senate. The academic senate is the highest normative body in higher education in the academic field. It consists of leaders, faculty deans, professors selected through an election process, non-professor vice lecturers elected by-election, the head of the library, and other elements determined by the academic senate concerned. ${ }^{12}$ The total of academic senate membership at IAIN Ponorogo is 14. This number is still dominated by 12 men, as illustrated in the table below. Therefore, it does not show a balanced distribution between men and women. However, the representation of 2 women in the senate membership has represented a policy to provide a particular portion for women as a form of gender-responsive campus implementation. In the future, it is hoped that the women's senate members will continue to increase along with the increasing number of female resources in the IAIN Ponorogo environment. Everything related to the senate's governance is regulated in the Organization and Work Procedure of IAIN Ponorogo in the Regulation of the Minister of Religion No. 49 of 2016.

Table 4. IAIN Ponorogo Academic Senate Membership for the Period 2018-2020

\begin{tabular}{|c|c|c|c|c|}
\hline \multirow{2}{*}{ No } & \multirow{2}{*}{ Period } & \multirow{2}{*}{ Total } & \multicolumn{2}{|c|}{ Gender } \\
\cline { 4 - 5 } & & & Male & Female \\
\hline 1 & $2018-2020$ & 14 & 12 & 2 \\
\hline
\end{tabular}

Source: IAIN Ponorogo Rector Decree

\section{Civil Servant Lecturer Participation in Research}

Becoming a Research University is a projection and big goal of IAIN Ponorogo. To achieve and realize this dream, building a tradition and learning culture for both lecturers and students is necessary. With this culture,

${ }^{11}$ M. Amin Abdullah, Multidisiplin, Interdisiplin, \& Transdisiplin; Metode Studi Agama o Studi Islam Di Era Kontemporer (Yogyakarta: IB Pustaka, 2020), p. 76.

${ }^{12}$ Richardus Eko Indrajit \& Richardus Djokopranoto, Manajemen Perguruan Tinggi Modern, p. 19. 
it is hoped that it will produce competitive human resources with global competitiveness. Learning culture can be done through the tradition of reading, writing, discussing and researching. If carried out seriously, the four critical traditions will become a leap of civilization towards Indonesia as a developed country. At the same time, a knowledge society is also built. A community group is the backbone of a nation that leads to innovation development or a nation that builds with innovation. ${ }^{13}$

The annual moment of the research grant held annually by Directorate of Islamic Religious Higher Education (DIKTIS) and Institute for Research and Community Service (LPPM) is an effort to build a competitive learning culture in the higher education environment. The research grant is intended for Islamic Higher Education lecturers throughout Indonesia.

Table 5. Civil Servant Lecturer Participation in Research

\begin{tabular}{|c|c|c|c|c|}
\hline \multirow{2}{*}{ No } & \multirow{2}{*}{ Year } & \multirow{2}{*}{ Total } & \multicolumn{2}{|c|}{ Gender } \\
\cline { 4 - 5 } & & & Male & Female \\
\hline 1 & 2018 & 87 & 52 & 35 \\
\hline 2 & 2019 & 135 & 81 & 54 \\
\hline 3 & 2020 & 92 & 57 & 35 \\
\hline
\end{tabular}

Source: IAIN Ponorogo Rector Decree

The data is deliberately displayed from 2018 to 2020 to know the movement of the numbers from year to year. An exceptionally significant increase occurred in 2019, while in 2020, the figure decreased. The reason is that the increasingly stringent research proposal selection process was starting from the plagiarism check stage to the reviewer team's assessment. So, many proposals dropped at the selection stage. A rigorous selection process is carried out to improve the quality of proposals hoping that the research results are suitable for publication in national and international scientific journals. Besides, from the table above, the study participants were still dominated by male lecturers. This fact becomes natural when looking back at the total number of female lecturers whose positions are below male lecturers. So, affirmative efforts are needed for female lecturers to be more active and enthusiastic about participating in research activities on campus.

${ }^{13}$ M. Hatta Rajasa, Cerita Cita Indonesia (Jakarta: Gramedia Pustaka Utama, 2015), p. 154. 
An affirmative action is an act that treats one sex differently, which in this context are women. Affirmative action aims to encourage women to have equal and equal access to men. Insights on affirmative action were also conveyed by Iklilah Muzayyanah during the Gender Responsive Semester Lesson Plan Preparation Workshop held by LPPM Ponorogo at Bale Resto, 15-16 November 2020.

According to Wardatun, the low literacy level among women is one of the priority agendas of many agendas that must be fought for women. It can be pursued through the systematization of struggle activities. The systematization of struggle is how the struggle to increase women's degree appears and is more intense and organized in a systematic movement. ${ }^{14}$ In this case, the Center for Gender and Child Studies must play an active role in embracing, encouraging, and providing insight to both male and female lecturers through workshops and Focus Group Discussions (FGDs) on the importance of implementing gender values in universities.

\section{Dissemination of IAIN Ponorogo Journal Manager in $\mathbf{2 0 2 0}$}

Scientific journals are a form of periodical publication that contains specific information precisely according to certain scientific fields. ${ }^{15}$ Scientific journals are a means to disseminate thoughts or research results that have gone through a process of acceptance, selection, peer-review, and publication. These processes are part of an effort to ensure that the articles meet journal quality standards and scientific validity. This side makes scientific journals have higher quality content when compared to other forms of information in general.

Scientific journals in higher education are a barometer of how far personnel from the entire academic community are active and productive in producing scientific work. Some of the essential meanings of journals' existence in higher education are that journals are media for the publication of research results. It is also the dissemination of knowledge, ideas and thoughts; revive academic culture; and what is no less important is bringing

\footnotetext{
${ }^{14}$ Atun Wardatun, Literasi dan Tradisi Kesetaraan; Dialektika Agama, Budaya, dan Gender (Lombok: Pustaka Lombok, 2019), p. 24.

${ }^{15}$ Hildawati Almah, 'Eksistensi Jurnal Ilmiah di Universitas Islam Negeri Alauddin Makassar (Perannya dalam Mendukung UIN Alauddin Makassar Menuju WorldClass University)', Khizanah Al-Hikmah: Jurnal Ilmu Perpustakaan, Informasi, dan Kearsipan, vol. 3, no. 2, Desember 2015, pp. 172-184 [http://journal.uin-alauddin. ac.id/index.php/khizanah-al-hikmah/article/view/1050].
} 
the name and introducing the campus in the national and international arena. ${ }^{16}$

The existence and reputation of scientific journals cannot be separated from the seriousness of their managers. Reputable journal status is determined by managers who have commitment and seriousness in managing the journal flow from the manuscript's initial receipt until the article is published both in print and online. So, it is not an exaggeration if a journal manager is called the fighter who devotes time, energy and thought to the journal so that it continues to grow and develop.

Table 6. Dissemination of IAIN Ponorogo Journal Manager

\begin{tabular}{|c|l|c|c|c|}
\hline \multirow{2}{*}{ No. Journal Name } & & \multirow{2}{*}{ Total } & \multicolumn{2}{c|}{ Gender } \\
\cline { 4 - 5 } & & & Male & Female \\
\hline 1 & Al-Tahrir: Jurnal Pemikiran Islam & 16 & 16 & \\
\hline 2 & Justicia Islamica: Jurnal Kajian Hukum dan Sosial & 20 & 14 & 6 \\
\hline 3 & Cendekia: Jurnal Kependidikan dan Kemasyarakatan & 10 & 4 & 6 \\
\hline 4 & Dialogia: Jurnal Studi Islam dan Sosial & 7 & 7 & \\
\hline 5 & Kodifikasia: Jurnal Penelitian Islam & 13 & 7 & 6 \\
\hline 6 & Pustakaloka: Jurnal Kajian Informasi dan Perpustakaan & 9 & 6 & 3 \\
\hline 7 & Muslim Heritage: Jurnal Dialog Islam dengan Realitas & 9 & 9 & \\
\hline 8 & el-Barka: Journal of Islamic Economics dan Business & 12 & 9 & 3 \\
\hline 9 & Al-Syakhsiyyah: Journal of Law and Family Studies & 6 & 4 & 2 \\
\hline 10 & InEJ: Indonesian Engagement Journal & 8 & 4 & 4 \\
\hline 11 & $\begin{array}{l}\text { INSECTA: Integrative Science Education and Teaching } \\
\text { Activity Journal }\end{array}$ & 16 & 8 & 8 \\
\hline 12 & ASANKA: Journal of Social Science and Education & 7 & 4 & 3 \\
\hline 13 & $\begin{array}{l}\text { ELTALL: English Language Teaching, Applied } \\
\text { Linguistic and Literature }\end{array}$ & 9 & 3 & 6 \\
\hline 14 & IJouGS: Indonesian Journal of Gender Studies & 4 & 2 & 2 \\
\hline 15 & WISDOM: Jurnal Pendidikan Anak Usia Dini & 6 & 3 & 3 \\
\hline 16 & $\begin{array}{l}\text { TSAQOFIYA: Jurnal Pendidikan Bahasa dan Sastra } \\
\text { Arab }\end{array}$ & 17 & 14 & 3 \\
\hline 17 & $\begin{array}{l}\text { IBRIEZ: Jurnal Kependidikan Dasar Islam Berbasis } \\
\text { Sains }\end{array}$ & 6 & 1 & 5 \\
\hline 18 & $\begin{array}{l}\text { Southeast Asian Journal of Islamic Education } \\
\text { Management }\end{array}$ & 25 & 21 & 4 \\
\hline 19 & QAULAN: Journal of Islamic Communication & 6 & 4 & 2 \\
\hline
\end{tabular}

${ }^{16}$ Personal Interview with the advisor of Rumah Jurnal IAIN Ponorogo, October 2020. 


\begin{tabular}{|c|l|c|c|c|}
\hline \multirow{2}{*}{ No. } & \multirow{2}{*}{ Journal Name } & \multirow{2}{*}{ Total } & \multicolumn{3}{|c|}{ Gender } \\
\cline { 4 - 5 } & & & Male & Female \\
\hline 20 & Rosyada: Islamic Guidance and Counseling & 6 & 3 & 3 \\
\hline 21 & MA'ALIM: Jurnal Pendidikan Islam & 7 & 4 & 3 \\
\hline \multicolumn{2}{|c|}{ Total } & & 147 & 72 \\
\hline
\end{tabular}

Source: Rumah Jurnal IAIN Ponorogo Website in 2020

Until the end of 2020, IAIN Ponorogo has 21 scientific journals under Rumah Jurnal. ${ }^{17}$ The data presented in the table above shows that the majority of journals have involved women as the management team. Although the quantity is not as much as men, this has become a form and evidence that women are not neglected because they also have competence in journal management, which is identical to that of men's journal managers. Also, along with the increasing number of superior and competent female human resources (lecturers) at IAIN Ponorogo, more and more women are involved in managing scientific journals.

\section{CONCLUSION}

Based on the data presented above, it appears that IAIN Ponorogo has implemented gender equality values in governance and activities held on campus. It can be seen from female lecturers' involvement in various sectors such as senate members, heads of departments, and journal managers. As for participation in the research field, the ratio between male and female lecturers is balanced. The relevant institutions need to take affirmative action to encourage female lecturers to increase their participation in the research field. Hence, efforts to systematize the struggle are needed, which increase women's degree through more intense and organized activities. Besides, the Center for Gender and Children Studies (PSGA) must also play an active role in embracing, encouraging, and providing insight to both male and female lecturers through workshops and FGDs on the importance of implementing gender values in higher education.

${ }^{17}$ Personal Interview with the administrator of Rumah Jurnal IAIN Ponorogo, October 2020 


\section{REFERENCES}

Abdullah, M. Amin. Multidisiplin, Interdisiplin, \& Transdisiplin; Metode Studi Agama \& Studi Islam Di Era Kontemporer. Yogyakarta: IB Pustaka, 2020.

Almah, Hildawati. 'Eksistensi Jurnal Ilmiah di Universitas Islam Negeri Alauddin Makassar (Perannya dalam Mendukung UIN Alauddin Makassar Menuju World-Class University)', Khizanah Al-Hikmah: Jurnal Ilmu Perpustakaan, Informasi, dan Kearsipan, vol. 3, no. 2, Desember 2015, pp. 172-184 [http://journal.uin-alauddin.ac.id/ index.php/khizanah-al-hikmah/article/view/1050].

Becker, Howard S. Tricks of the Trade; How to Think about Your Research While You're Doing It. USA: The University of Chicago Press, 1998. Creswell, John W. Research Design; Qualitative, Quantitative, and Mixed Methods Approaches. USA: Sage Publication, 2014.

IAIN Ponorogo. Buku Wisuda 2019 Semester Gasal Tahun Akademik 2019/2020. IAIN Ponorogo, 2019.

Inayatillah. 'Potret Relasi Gender di UIN Ar-Raniry', Gender Equality: International Journal of Child and Gender Studies, vol. 3, no. 2, September 2017, pp. 49-66 [https://jurnal.ar-raniry.ac.id/index. php/equality/article/view/3442].

Indrajit, Richardus Eko, and Richardus Djokopranoto. Manajemen Perguruan Tinggi Modern. Jakarta: Atma Jaya\&Perbanas, 2006.

Jamal, Amina. 'Gendered Islam and Modernity in the Nation-Space:

Women's Modernism in the Jamaat-e-Islami of Pakistan', Feminist Review, vol. 91, no. 1 (2009), pp. 9-28.

Karniawati, Nia. Kinerja Dosen Perempuan: Studi Relasi Gender di Unikom. Unikom Repository, 2013. [https://repository.unikom. ac.id/30655/].

Nye, F. Ivan. Role Structure and Analysis of the Family. USA: Sage Publication, 1976.

Pandiangan, Dingse et al. 'Profil Gender Sumber Daya Manusia Universitas Sam Ratulangi Tahun 2019 Berbasis Penilaian Gender (Gender Assessment)', JPAI: Jurnal Perempuan dan Anak Indonesia, vol. 2, no. 1, 2020, pp. 31-42 [https://ejournal.unsrat.ac.id/index.php/ jpai/article/view/28277].

Pye, Michael et. al. Religious Harmony; Problem, Practice, and Education. Jerman: 2006. 
Rajasa, M. Hatta. Cerita Cita Indonesia. Jakarta: Gramedia Pustaka Utama, 2015.

Wardatun, Atun. Literasi Dan Tradisi Kesetaraan; Dialektika Agama, Budaya, Dan Gender. Lombok: Pustaka Lombok, 2019. 